\title{
The role of local environment and geographical distance in determining community composition of arbuscular mycorrhizal fungi at the landscape scale
}

\author{
Christina Hazard ${ }^{1}$, Paul Gosling ${ }^{2}$, Christopher J van der Gast ${ }^{3}$, Derek T Mitchell ${ }^{1}$, \\ Fiona M Doohan ${ }^{1}$ and Gary D Bending ${ }^{2}$ \\ ${ }^{1}$ School of Biology and Environmental Science, University College Dublin, Dublin, Ireland; \\ ${ }^{2}$ School of Life Sciences, University of Warwick, Coventry, UK and ${ }^{3}$ NERC Centre for Ecology and \\ Hydrology, Oxford, UK
}

\begin{abstract}
Arbuscular fungi have a major role in directing the functioning of terrestrial ecosystems yet little is known about their biogeographical distribution. The Baas-Becking hypothesis ('everything is everywhere, but, the environment selects') was tested by investigating the distribution of arbuscular mycorrhizal fungi (AMF) at the landscape scale and the influence of environmental factors and geographical distance in determining community composition. AMF communities in Trifolium repens and Lolium perenne roots were assessed in $\mathbf{4 0}$ geographically dispersed sites in Ireland representing different land uses and soil types. Field sampling and laboratory bioassays were used, with AMF communities characterised using 18S rRNA terminal-restriction fragment length polymorphism. Landscape-scale distribution of AMF was driven by the local environment. AMF community composition was influenced by abiotic variables ( $\mathrm{pH}$, rainfall and soil type), but not land use or geographical distance. Trifolium repens and $L$. perenne supported contrasting communities of AMF, and the communities colonising each plant species were consistent across pasture habitats and over distance. Furthermore, L. perenne AMF communities grouped by soil type within pasture habitats. This is the largest and most comprehensive study that has investigated the landscapescale distribution of AMF. Our findings support the Baas-Becking hypothesis at the landscape scale and demonstrate the strong influence the local environment has on determining AMF community composition.

The ISME Journal (2013) 7, 498-508; doi:10.1038/ismej.2012.127; published online 25 October 2012
\end{abstract}

Subject Category: microbial population and community ecology

Keywords: arbuscular mycorrhizal fungi; biogeography; diversity; host preference; land use; soil type

\section{Introduction}

The biogeography of macroorganisms has been thoroughly investigated while that of microorganisms has not (Fitter, 2005). However, with improvements in the assessment of microbial diversity using molecular-based approaches, a new interest in understanding microbial biogeography has emerged (Martiny et al., 2006; Prosser et al., 2007; Ramette and Tiedje, 2007a; Nemergut et al., 2011). Traditionally, microbial biogeographical patterns were assumed to follow the Baas-Becking hypothesis, which predicted that 'everything is everywhere, but, the environment selects' (Baas-Becking, 1934) or in other words, microorganisms are not dispersal

Correspondence: C Hazard, Institute of Biological and Environmental Sciences, Cruickshank Building, University of Aberdeen, Aberdeen AB24 3UU, UK.

E-mail: christina.hazard@abdn.ac.uk

Received 6 February 2012; revised 10 September 2012; accepted 12 September 2012; published online 25 October 2012 limited and the resulting microbial community is shaped by the local environment. Recent research suggests that microbial biogeographical patterns are more complex than the Baas-Becking hypothesis predicts. The effect of geographical distance with or without an environmental effect has been shown, which suggests that past events (e.g., dispersal limitation, speciation and extinction) can affect current microbial distributions (Green et al., 2004; Ramette and Tiedje, 2007b; Wang et al., 2008; Oakley et al., 2010; Schauer et al., 2010; Martiny et al., 2011; van der Gast et al., 2011).

Soil microbes are genetically diverse, abundant and functionally important organisms (Roesch et al., 2007; van der Heijden et al., 2008), and thus understanding there biogeographical patterns and what drive them is key for maintaining ecosystems under a changing environment. Various biotic and abiotic factors and biological processes have been theorised to have an impact on microbial biogeographical patterns (reviewed by Martiny et al., 2006 and Ramette and Tiedje, 2007a). Several observational 
studies have identified various edaphic variables that influence soil bacteria and fungal community compositions, and some of which have been related to driving distributions. Soil pH, e.g., has been identified to strongly influence the biogeographical patterns of soil bacteria (Fierer and Jackson, 2006; Lauber et al., 2009). While, the gap in knowledge of microbial biogeography is narrowing, important groups of soil microbes have been neglected.

Arbuscular mycorrhizal fungi (AMF) are an important soil microbial group, which form a mutualistic symbiosis with plant roots. Through their impacts on plants, AMF affect multiple ecosystem functions and processes, including nutrient cycling, plant productivity and competition (Hartnett and Wilson, 1999; van der Heijden et al., 2003; Scheublin et al., 2007), and plant diversity (van der Heijden et al., 1998a, b; Klironomos et al., 2000; O'Connor et al., 2002). Approximately $65 \%$ of the world's vascular plant species associate with AMF, the symbiosis occurring in nearly all terrestrial ecosystems (Wang and Qiu, 2006; Brundrett, 2009).

Currently, 226 AMF species have been described in the phylum Glomeromycota using spore morphology (Schüßler's Glomeromycota phylogeny, http://www.lrz-muenchen.de/ schuessler/ amphylo/; 4 January 2011). However, this is likely an underestimation of AMF global richness (Opik et al., 2010; Kivlin et al., 2011). The current understanding of the geographic distributions of AMF species is limited. Several factors have been identified that may influence AMF distributions, including abiotic (e.g., soil physico-chemical properties) and biotic (e.g., host plant) factors, and intrinsic properties of species (e.g., dispersal ability) (reviewed by Chaudhary et al., 2008). However, most data remain site specific, and there are relatively few studies at the landscape or larger geographical scales. The role of geographical distance and the local environment in shaping AMF distributions at various spatial scales and whether AMF distributions are more complex than the Baas-Becking hypothesis predicts remains to be determined.

Traditionally, surveys of AMF diversity have been based on the collection and morphological identification of spores; a method acknowledged as being limited in its detection capacity (Sanders, 2004; Chaudhary et al., 2008; Rosendahl, 2008). With advances in molecular methods, enabling AMF actively colonising plant roots to be identified, AMF diversity studies have improved over the years, thus making AMF biogeography research more feasible. Recent evidence from a molecular-based study suggests that land management can impact the diversity and distribution of AMF over the landscape, with conventionally managed farm soils showing lower diversity and greater similarity of AMF communities than organically managed soil over the landscape scale (van der Gast et al., 2011). Meta-analysis studies, availing of published DNA sequences and metadata, suggest that the local environment and geographical distance have a role in driving distribution patterns at the global scale (Opik et al., 2006, 2010; Kivlin et al., 2011). Factors such as climatic zone, habitat and plant community type, and soil temperature and moisture have been suggested to contribute to global patterns of AMF distribution (Opik et al., 2006, 2010; Kivlin et al., 2011).

Several studies have shown that co-occurring plant species can host different AMF communities (Helgason et al., 2002; Vandenkoornhuyse et al., 2002, 2003; Sýkorová et al., 2007a; Opik et al., 2009). Such studies have investigated the AMF communities of co-occurring plants from only one or two sites. It is unknown whether AMF community differences between plant hosts only represents 'local host preferences' or is a phenomenon that also occurs at larger geographical scales (Sýkorová et al., 2007a). Evidence from Opik et al. (2010), showing a significant relationship between AMF distribution patterns and occurrence in host angiosperm superorders, suggests that host preference effects may occur at the global scale. To make biogeographical inferences without the confounding effect of host preferences, AMF surveys across sites need to be carried out using the same plant species. As not all plant species will occur everywhere, a field soil bioassay bait-plant approach using a defined genotype could be a useful strategy in studies of AMF biogeography (van der Gast et al., 2011).

Here, we investigate AMF distribution at the landscape scale and the role of the local environment and geographical distance in determining community composition. The community composition of AMF on field soil bioassay bait-plant roots was assessed for 40 geographically dispersed sites representing different land uses and soil types. Naturally occurring plants were also collected from a subset of sites to compare AMF communities of cooccurring plant species and between different experimental approaches (bait plants vs field plants). AMF community composition of plant roots was determined using terminal-restriction fragment length polymorphism (T-RFLP) of 18S rRNA, a method that has previously been shown to be useful for characterising AMF communities of plant roots (Vandenkoornhuyse et al., 2003; Johnson et al., 2004; Mummey et al., 2005; Lekberg et al., 2007; Dumbrell et al., 2010; van der Gast et al., 2011).

\section{Materials and methods}

Field sites

Field sites were chosen from a pool of 1310 locations of the Irish National Soils Database (Fay et al., 2007a). The 40 sites selected for this study represented the major Irish soil types and land uses and covered a geographically large area in the Republic of Ireland (Figure 1). Eight soil types were 
500

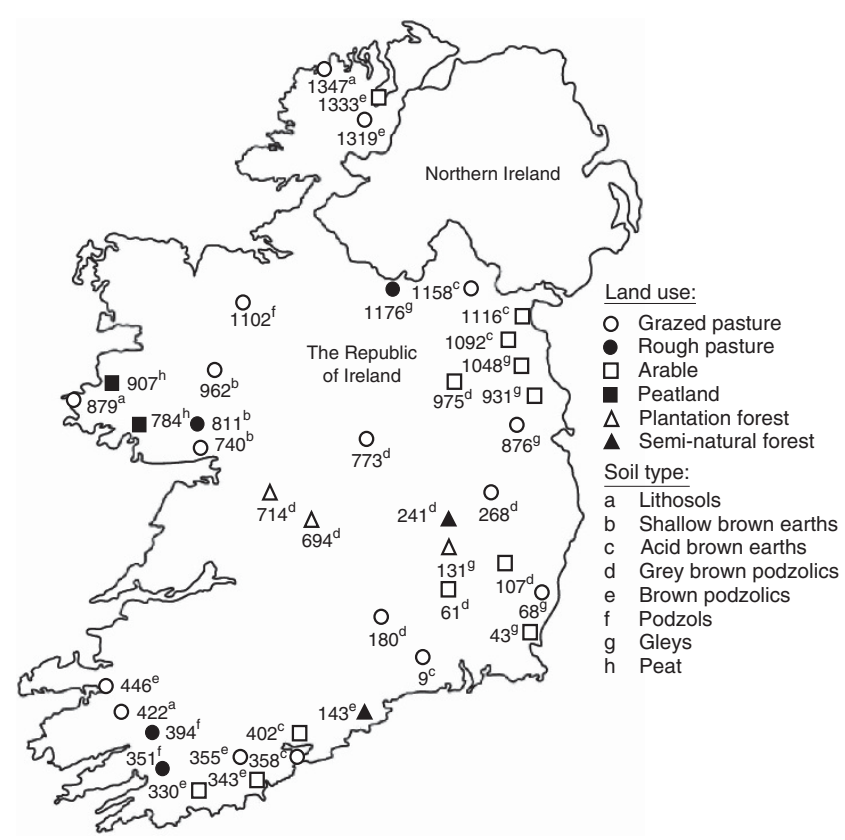

Figure 1 Site location, land use and soil type of the 40 Irish National Soils Database sites that were sampled for arbuscular mycorrhizal fungi in the Republic of Ireland.

considered; lithosols, shallow brown earths, acid brown earths, grey brown podzolics, brown podzolics, podzols, gleys and peat (for a detailed description of these soil types, see Fay et al., 2007b). According to land use, the 40 sites included 21 pastures (17 grazed and 4 rough grazed pastures (sites with environmental characteristics and management between those of a pasture and peatland)), 12 arable fields (tilled), 2 peatlands (raised bogs) and 5 forests ( 3 plantations and 2 seminatural forests). The majority of sites consisted of pasture and arable sites, such that each soil type found in these two land-use categories was replicated by three sites (pasture and arable sites representing seven and four soil types, respectively). The distance between the sites ranged from 7 to $392 \mathrm{~km}$. Further site descriptions, locations and soil chemical parameters (extractable phosphorus, \% organic carbon, \% nitrogen, organic matter content and $\mathrm{pH}$; provided by Kelly and Carton, 2009) for each of the 40 sites are given in Supplementary Table S1.

\section{Sampling strategy}

A $30 \times 30$ metre plot was established at each of the 40 sites, with the plot centred on the sites' global positioning system point. Soil and plant samples were collected in August 2006. Within each plot, 20 soil samples were collected randomly, using a standard $20 \mathrm{~cm}$ depth $\times 5 \mathrm{~cm}$ diameter Edelman soil auger (Eijkelkamp Agrisearch Equipment BV, Giesbeek, The Netherlands). The soil samples from each site were bulked, mixed and stored at $4{ }^{\circ} \mathrm{C}$ until use.

The field soil was used for a bioassay with Trifolium repens L. to bait for AMF. This plant species was chosen as the bait plant due to its abundance in Irish pastures, its ease in growing and because it is highly mycorrhizal. Sterile pots $(8 \times$ $8 \times 8 \mathrm{~cm}$ ) were filled with a mixture of field soil and autoclaved sand (1:1 mix), into which 10 surfacesterilised seeds of T. repens were sown. Seeds were surface sterilised in $2.5 \%$ sodium hypochlorite for $15 \mathrm{~min}$ and rinsed three times in sterile water. Three replicate pots were prepared per field site. Twentyfive negative control pots contained seedlings of T. repens grown in autoclaved field soil and sand (1:1 mix). Pots were randomised in a growth chamber where they were grown for 3 months under environmentally controlled conditions $(8 \mathrm{~h}$ dark/ $16 \mathrm{~h}$ light $\left(120 \mu \mathrm{mol}\right.$ photons $\left.\mathrm{m}^{-2} \mathrm{~s}^{-1}\right)$ cycle, constant temperature of $20^{\circ} \mathrm{C}$ ) and watered twice a week. At harvest, all plant roots were carefully and thoroughly washed free of soil with water. From each of the three replicate pots per site, roots from five randomly selected plants were bulked $(n=3$ bulk-root samples per site), and rinsed three times with deionised water, blotted dry, frozen with liquid nitrogen and stored at $-80^{\circ} \mathrm{C}$.

Lolium perenne L. and T. repens L. plants were collected from a subset of the pasture sites (16 sites for $L$. perenne, 13 sites for T. repens, with 12 sites commonly sampled for both species). These plant species were chosen for collection as they were the most frequent and abundant plant species across the pasture sites. For each plant species, five random samples were collected in each plot using a shovel to excavate a block of turf $15 \times 15 \mathrm{~cm}$ by $30 \mathrm{~cm}$ deep in which the plant species of interest dominated. These turf samples were stored at $4{ }^{\circ} \mathrm{C}$ and the roots were processed from these samples within 2 weeks from collection. Soil debris was thoroughly washed from plant roots with water. From each of the five turf samples per site, five randomly selected plants were bulked ( $n=5$ bulk-root samples per site), and the roots were further processed as described above.

\section{Terminal-restriction fragment length polymorphism} Frozen root samples were homogenised (using a mortar and pestle) and total DNA was extracted from $100 \mathrm{mg}$ of homogenate using the DNeasy Plant Mini Kit (QIAGEN, Hilden, Germany). A 550-bp region of the $18 \mathrm{~S}$ rRNA was amplified using the universal eukaryotic primer NS31 (Simon et al., 1992) and the AMF primer AM1 (Helgason et al., 1998). NS31 and AM1 were $5^{\prime}$ end-labelled with the fluorescent dyes FAM and HEX, respectively. The primer set chosen amplifies most AMF species, except Archaeospora, Paraglomus and some Glomus group B species (Redecker, 2000). Also, some non-specific amplification can occur (Douhan et al., 2005). To assess the amount of error due to non-specific amplification, representative samples were cloned and Sanger sequenced; amplification error was estimated based on these data and found to be minimal (see Supplementary Materials and methods). 
PCR was conducted in a volume of $25 \mu$ l and contained $21 \mu \mathrm{l}$ of Megamix (Microzone, Haywards Heath, UK), $25 \mathrm{pmol}$ of each primer, $1 \mu \mathrm{l}$ of bovine serum albumin and $2.5 \mu \mathrm{l}$ of template DNA. Amplification was performed using a GeneAmp PCR System 9700 (Applied Biosystems, Foster City, CA, USA) and a programme consisting of: $3 \mathrm{~min}$ at $95^{\circ} \mathrm{C}$; 9 cycles of $1 \mathrm{~min}$ at $94^{\circ} \mathrm{C}, 1 \mathrm{~min}$ at $58^{\circ} \mathrm{C}, 2 \mathrm{~min}$ at $72{ }^{\circ} \mathrm{C} ; 20$ cycles of $30 \mathrm{~s}$ at $94^{\circ} \mathrm{C}, 1 \mathrm{~min}$ at $58^{\circ} \mathrm{C}, 3 \mathrm{~min}$ at $72^{\circ} \mathrm{C}$; a final extension for $7 \mathrm{~min}$ at $72^{\circ} \mathrm{C}$. PCR products were purified using the QIAquick PCR Purification Kit (QIAGEN).

For T-RFLP analysis, purified PCR products were digested with the restriction enzymes HinfI (New England BioLabs, Ipswich, MA, USA) and Hsp92II (Promega, Madison, WI, USA) in two separate reactions. Although these enzymes have previously been shown to produce useful terminal-restriction fragments (T-RFs; Vandenkoornhuyse et al., 2003; Johnson et al., 2004), the adequacy of the produced T-RFs to represent the AMF community was verified in subsequent analyses (see Supplementary Materials and methods). Each $20 \mu \mathrm{l}$ digestion reaction contained $15 \mu \mathrm{l}$ of PCR product, 2 units of enzyme, $10 \times$ manufacturer's buffer and was incubated for $4 \mathrm{~h}$ at $37^{\circ} \mathrm{C}$ followed by $20 \mathrm{~min}$ at $80^{\circ} \mathrm{C}$ to denature the enzymes. The digested products were purified by centrifugation through Millipore Multiscreen Filter Plates (Millipore, Bedford, MA, USA) filled with Sephadex G-50 Superfine (Sigma-Aldrich, St Louis, MO, USA). Mixtures containing $1 \mu \mathrm{l}$ of each digest product, $0.15 \mu \mathrm{l}$ of GeneScan-500 ROX internal-lane size standard (Applied Biosystems) and $9.85 \mu \mathrm{l}$ of HiDi Formamide (Applied Biosystems) were denatured at $95{ }^{\circ} \mathrm{C}$ for $5 \mathrm{~min}$ and cooled on ice before being analysed on an automated capillary sequencer 3130X1 Genetic Analyser (Applied Biosystems). The resulting T-RF profiles were analysed using the programme GeneMarker v1.5 (SoftGenetics, State College, PA, USA), a threshold of 50 fluorescent units, a fragment range of $75-450 \mathrm{bp}$, and a bin width of $2 \mathrm{bp}$. A T-RF presence/absence matrix was constructed using the four restriction enzyme/primer combination, and for each site, single T-RF profiles from replicate bait T. repens, field T. repens and field L. perenne samples were combined, respectively.

\section{Statistical analyses of data}

The total number of T-RFs for each site was calculated and the significance of differences in the mean number of T-RFs across plant types, land uses and soil types was determined using one-way analysis of variance. Statistical tests were performed using SPSS v12.0.1 (SPSS Inc., Chicago, IL, USA). To assess sampling efficiency, estimates of the total number of T-RFs for each site, based on the firstorder Jackknife estimate, were calculated in PC-ORD v5.0 (McCune and Mefford, 1999).

Multidimensional scaling and hierarchical cluster analysis were used to compare the AMF communities within the different plant types, land uses and soil types across sites. Bray-Curtis resemblance matrices were generated based on raw presence/absence T-RF data (Bray and Curtis, 1957; Clarke, 1993). The resemblance matrices were plotted in two dimensions by non-metric multidimensional scaling (NMDS) ordination (25 restarts, 0.01 minimum stress, Kruskall fit scheme 1, stress value $\leqslant 0.18$ ) (Kruskal and Wish, 1978). Stress (goodness of fit of the plot) was calculated as described by Kruskal (1964); a stress level of $\leqslant 0.1$ corresponds to an ideal ordination (Clarke, 1993). Dendrograms were constructed by hierarchical cluster analysis (group-average linking) using the Bray-Curtis resemblance matrices (Clarke, 1999). Clusters were superimposed on the NMDS plot to form ellipses at arbitrary resemblance levels of slices drawn through the dendrograms $(20 \%, 40 \%$ and $60 \%$ ). One-way ANOSIM (analysis of similarity) was performed on Bray-Curtis resemblance matrices (incorporating 999 permutations for R statistics) to determine the significance of differences between plant types, land uses and soil types. All procedures were computed using PRIMER v6.1.9 (Primer-E Ltd, Plymouth, UK).

Two complementary approaches, direct ordination and Mantel test (Tuomisto and Ruokolainen, 2006), were used to relate the variability in the distribution of AMF to environmental factors (land use, soil type, extractable phosphorus, nitrogen, organic carbon, organic matter, $\mathrm{pH}$ and rainfall) and geographical distance. For the direct ordination approach, principle coordinates of neighbour matrices (PCNM) were calculated from grid coordinates of the sites using the 'pcnm' function of the 'vegan' package with the R language (R Development Core Team, Vienna, Austria). PCNM were used as explanatory spatial variables for canonical correspondence analysis (Borcard and Legendre, 2002; Borcard et al., 2004; Dray et al., 2006). PCNM and environmental variables that significantly explained variation in AMF communities were determined with forward selection (999 Monte Carlo permutations; $\alpha<0.05$ ) and used in canonical correspondence analysis (Peres-Neto et al., 2006). Partial canonical correspondence analysis was performed when both PCNM and environmental variables were significant. Analyses were performed in CANOCO for Windows v4.5 (ter Braak and Smilauer, 2002).

For the Mantel approach (Mantel, 1967; Smouse et al., 1986; Rossi, 1996; Martiny et al., 2006), AMF similarity matrices for each plant type, using raw presence/absence T-RF data, were calculated using the Bray-Curtis index of similarity in PAST v1.22 (Hammer et al., 2001). Similarity matrices for environmental factors were generated by calculating the absolute difference of values between sites for each quantitative factor and for the categorical data-sites with the same land use or soil type were coded with a zero and when different with a one. Lower tailed partial Mantel tests were conducted in 
XLSTAT 2002 (Addinsoft, New York, NY, USA), with $P$-values based on 9999 permutations.

\section{Results}

Terminal-restriction fragments

A total of 446 T-RFs, ranging from 75 to $450 \mathrm{bp}$, were detected from the 265 bulk-root samples taken across the 3 plant types and the 40 sites surveyed. HinfI-based analyses accounted for 108 FAMlabelled and 105 HEX-labelled T-RFs and Hsp92II for 124 FAM-labelled and 109 HEX-labelled T-RFs of the profiles. There was a greater proportion of rare T-RFs compared with frequent T-RFs; 75 T-RFs occurred in $1 \%$ of the bulk-root samples and only 38 T-RFs occurred in at least $20 \%$ of the samples. The mean number of T-RFs per bulk-root sample was $17 \pm 13$ for bait T. repens, $60 \pm 25$ for field T. repens and $29 \pm 20$ for field $L$. perenne. The mean number of T-RFs per site was $34 \pm 19(n=40$; all sites) for bait $T$. repens, $136 \pm 18(n=13)$ for field T. repens, $67 \pm 26(n=16)$ for $L$. perenne and $183 \pm 30$ $(n=12$; pasture sites only) when including all plant types. Mean estimates of total T-RFs for sites based on first-order Jackknife estimates were $149 \pm 22$ for field T. repens, and $72 \pm 38$ for field $L$. perenne.

\section{Effect of environmental factors and geographic distance on AMF communities}

Based on the direct ordination approach, the AMF community composition on the bait $T$. repens was significantly influenced by only 1 of the 29 PCNM vectors, rainfall, peat land use, and the peat and lithosol soil types, and the field $L$. perenne by the gleys soil type, $\mathrm{pH}$ and rainfall. These variables were retained by the forward selection process and used in canonical correspondence analysis models, respectively. PCNM explained only $3.8 \%$ of the variation compared with $16 \%$ by environment of the bait T. repens AMF community (Table 1). Environment explained $31 \%$ of the variation in the field L. perenne AMF community (Table 1).

Table 1 Canonical correspondence analyses for determination of percent variation in arbuscular mycorrhizal fungal communities of the different plant types explained by environment and principle coordinates neighbour matrices (PCNM)

\begin{tabular}{|c|c|c|c|}
\hline$\%$ Of variation & $\begin{array}{l}\text { Bait Trifo- } \\
\text { lium repens }\end{array}$ & $\begin{array}{l}\text { Field Trifo- } \\
\text { lium repens }\end{array}$ & $\begin{array}{l}\text { Field Lolium } \\
\text { perenne }^{\mathrm{c}}\end{array}$ \\
\hline Environment & 16.01 & - & 31.10 \\
\hline PCNM & 3.84 & - & - \\
\hline Environment + PCNM & 2.08 & - & - \\
\hline Undetermined & 80.15 & 100 & 68.90 \\
\hline
\end{tabular}

Abbreviation: AMF, arbuscular mycorrhizal fungi.

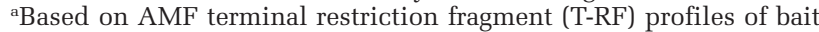
plants grown in soils from 36 sites.

${ }^{b}$ Based on AMF T-RF profiles of plants collected from 12 pasture sites. 'Based on AMF T-RF profiles of plants collected from 15 pasture sites.
Based on the partial Mantel approach, variation of the field $L$. perenne AMF beta diversity significantly correlated with soil $\mathrm{pH}(r=-0.476, P<0.0001)$, and rainfall $(r=-0.332, P<0.0001)$ (Table 2). No significant correlation was observed between the variation in AMF beta diversity of the bait and field T. repens with environmental variables or geographic distance (Table 2).

\section{AMF community of plant types: bait and co-occurring field plants}

The majority of T-RFs were unique to one plant type (bait T. repens: $11 \%$, field T. repens: $28 \%$ and field L. perenne: $24 \%$ ) and only $10 \%$ of T-RFs were shared between all plant types, $6 \%$ between bait and field T. repens, $17 \%$ between field $T$. repens and L. perenne, and the remaining $4 \%$ between bait $T$. repens and field $L$. perenne. The mean number of T-RFs was significantly different between plant types sampled across common sites $(P=0.001$; all pairwise comparisons being significantly different, $P<0.007$ ) (Table 3). Higher numbers of T-RFs were obtained from field $T$. repens and $L$. perenne, as compared with the bait T. repens (numbers being greatest for field-collected T. repens) (Table 3). The AMF community of the different plant types clustered as distinct groups on the NMDS plot with each group having a within-group similarity of $>40 \%$ (average similarity within bait $T$. repens was $51.97 \%$, field $T$. repens with $70.72 \%$ and field L. perenne with $47.89 \%$ ) and a between-group similarity of $20-29 \%$ (bait $T$. repens-field $T$. repens $=24$; field $T$. repens - field $L$. perenne $=29$ ), based on the cluster analysis (Figure 2a). The plant type groups were all significantly different from each other (global $R=0.946, P=0.001$; all pairwise comparisons, $P=0.001$ ).

Differences in the frequency and abundance of phylogenetically defined sequence groups were observed when comparing between the plant type samples from site 1176 (Supplementary Figure S1). These differences in the distribution of AMF sequences between the three plant types correspond with the results of T-RFLP analysis, which demonstrated that the AMF communities of the plant types were significantly different.

AMF community of different land uses and soil types The mean number of T-RFs across sites between land uses was not significantly different $(P=0.144)$ (Table 3). The AMF communities of the bait T. repens did not show distinct groupings based on land use, with $40 \%$ similarity ellipses superimposed on the NMDS plot encompassing a mixture of land uses (Figure 2b). The ANOSIM test, performed using the land use categories; arable, pasture (grazed and rough) and forest (plantation and seminatural), was not significant (global $R=0.085, P=0.125$ ). 
Table 2 Partial Mantel test analyses for the association between arbuscular mycorrhizal fungi community structure and both environmental factors and geographical distance

\begin{tabular}{|c|c|c|c|c|c|c|c|}
\hline \multirow[t]{2}{*}{ Parameter } & \multirow[t]{2}{*}{ Control for } & \multicolumn{2}{|c|}{ Bait Trifolium repens ${ }^{\mathrm{a}}$} & \multicolumn{2}{|c|}{ Field Trifolium repens ${ }^{\mathrm{b}}$} & \multicolumn{2}{|c|}{ Field Lolium perenne } \\
\hline & & $\mathrm{r}$ & $\mathrm{P}$ & $\mathrm{r}$ & $\mathrm{P}$ & $\mathrm{r}$ & $\mathrm{P}$ \\
\hline Soil type & Distance & 0.040 & 0.839 & 0.178 & 0.924 & -0.205 & 0.034 \\
\hline Land use & Distance & -0.037 & 0.181 & - & - & - & - \\
\hline Rainfall (mm year ${ }^{-1}$ ) & Distance & -0.067 & 0.045 & -0.079 & 0.259 & -0.332 & 0.0001 \\
\hline $\mathrm{P}\left(\mathrm{mg} \mathrm{kg}^{-1}\right)$ & Distance & -0.104 & 0.005 & -0.133 & 0.139 & -0.129 & 0.097 \\
\hline $\mathrm{C}(\%)$ & Distance & -0.092 & 0.011 & 0.019 & 0.567 & -0.013 & 0.448 \\
\hline N (\%) & Distance & -0.019 & 0.306 & -0.019 & 0.436 & -0.116 & 0.118 \\
\hline $\mathrm{OM}(\%)$ & Distance & -0.095 & 0.010 & 0.037 & 0.611 & -0.033 & 0.374 \\
\hline $\mathrm{pH}$ & Distance & -0.067 & 0.048 & -0.118 & 0.180 & -0.476 & 0.0001 \\
\hline Distance & Soil type & -0.037 & 0.180 & 0.019 & 0.562 & 0.047 & 0.652 \\
\hline Distance & Land use & -0.028 & 0.228 & - & - & - & - \\
\hline Distance & Rainfall & -0.007 & 0.425 & -0.087 & 0.252 & 0.079 & 0.784 \\
\hline Distance & $\mathrm{P}$ & -0.021 & 0.290 & -0.132 & 0.144 & 0.013 & 0.550 \\
\hline Distance & $\mathrm{C}$ & -0.019 & 0.327 & 0.007 & 0.517 & 0.011 & 0.541 \\
\hline Distance & $\mathrm{N}$ & -0.027 & 0.263 & -0.059 & 0.328 & -0.003 & 0.496 \\
\hline Distance & $\mathrm{OM}$ & -0.020 & 0.309 & 0.040 & 0.630 & 0.007 & 0.531 \\
\hline Distance & $\mathrm{pH}$ & -0.022 & 0.292 & -0.121 & 0.172 & 0.011 & 0.539 \\
\hline
\end{tabular}

Abbreviations: AMF, arbuscular mycorrhizal fungi; OM, organic matter.

$P$-values significant after Bonferroni correction for multiple comparisons $(0.05 / 16=0.0031 ; 0.05 / 14=0.0036)$ are in bold .

aBased on AMF terminal restriction fragment (T-RF) profiles of bait plants grown in soils from 36 sites.

${ }^{\mathrm{b} B a s e d}$ on AMF T-RF profiles of plants collected from 12 pasture sites.

${ }^{\mathrm{c} B a s e d}$ on AMF T-RF profiles of plants collected from 15 pasture sites.

Table 3 Number of terminal-restriction fragments (T-RFs) between the plant types from commonly sampled pasture sites, and land uses based on the bait Trifolium repens from the 40 study sites

\begin{tabular}{lcccc}
\hline & $\begin{array}{c}\text { No. of } \\
\text { sites }\end{array}$ & $\begin{array}{c}\text { Total no. } \\
\text { of T-RFs }\end{array}$ & $\begin{array}{c}\text { Mean T-RFs } \\
\text { across sites }\end{array}$ & s.d. \\
\hline Plant type & & & & \\
$\quad$ Bait T. repens & 12 & 121 & 42 & 17 \\
Field T. repens & 12 & 251 & 136 & 19 \\
Field L. perenne & 12 & 217 & 71 & 25 \\
All plant types & 12 & 403 & 183 & 30 \\
& & & & \\
Land use & 21 & 165 & 39 & 18 \\
Pasture & 12 & 105 & 25 & 19 \\
Arable & 5 & 71 & 34 & 13 \\
Forest & 2 & 68 & 33 & 18 \\
Peatland & 40 & 179 & 35 & 19 \\
$\quad$ All land uses & & & &
\end{tabular}

The mean number of bait $T$. repens T-RFs among different soil types of pastures or arable sites was not significantly different (pasture: $P=0.390$, arable: $P=0.192$ ), nor were the field $L$. perenne mean number of T-RFs among different soil types of pastures $(P=0.860)$ (Table 4). The NMDS plot of the AMF community of $L$. perenne from pasture sites with different soil types shows groupings with $60 \%$ similarity ellipse deduced by cluster analysis (Figure 2c), and ANOSIM analysis indicated soil type-based discrimination of AMF community composition $(P=0.008$; global $R=0.315)$. There were no significant groupings of soil types with the bait T. repens from pastures (global $R=0.038, P=0.355$ ) or arable sites (global $R=-0.029, P=0.590$ ). Field $T$. repens were not included in the above analyses due to insufficient replication $(n<3)$ in the number of sites for some of the soil types.

\section{Discussion}

Our findings suggest that at the landscape scale the distribution of AMF was being driven by local environment rather than geographical distance. Therefore, our results do not reject the Baas-Becking hypothesis. There are very few studies on fungi that have investigated landscape-scale distribution patterns. Interestingly, Green et al. (2004) only detected small changes in ascomycete communities over increasing geographic distances (maximum distance $100 \mathrm{~km}$ ) and suggested that abiotic variables at the local scale were driving community compositions. However, Lekberg et al. (2007) found that both soil texture and geographical distance (maximum distance $25 \mathrm{~km}$ ) influenced the AMF community of Zea mays from 10 arable sites. This was recently supported by van der Gast et al. (2011), who showed that farming practice (organic vs conventional) and geographical distance (sites within $250 \mathrm{~km}$ ) affected AMF community composition of bait plants from nine locations. A synthesis of microbial studies across different spatial scales suggests that the relationship between geographic distance and environmental effects on microbial communities may be related to the scale of the study, with a geographic distance effect at the large scale, an environmental effect at the small scale, and both effects or environmental only at the landscape scale (Martiny et al., 2006). Landscape-scale studies of AMF support this statement, but at the global scale 
a
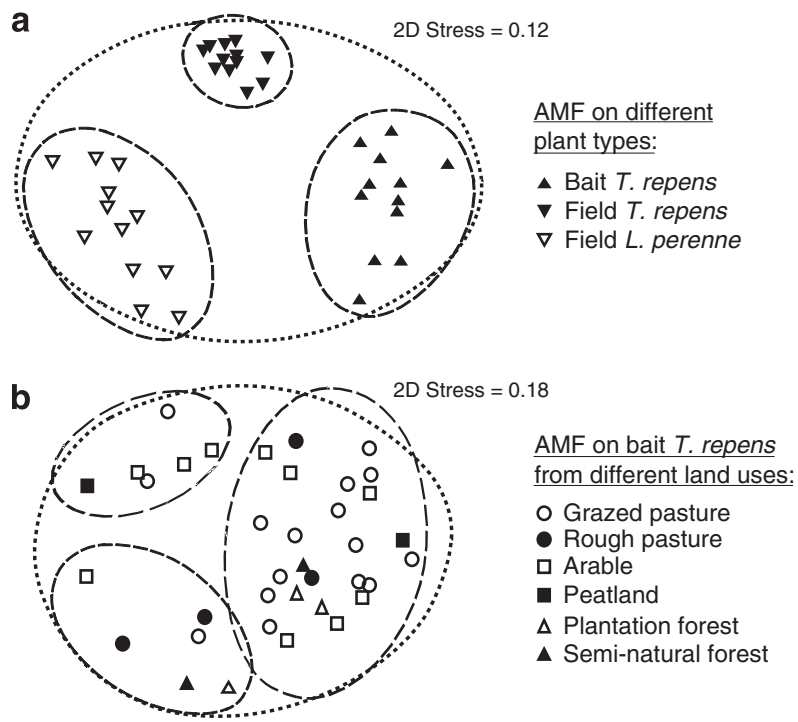

C

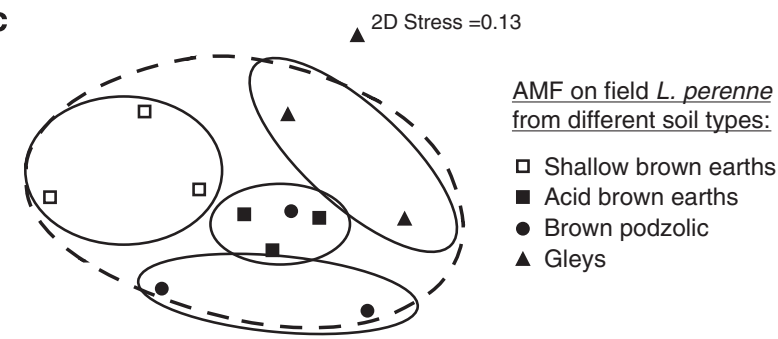

Superimposed hierarchical clusters:

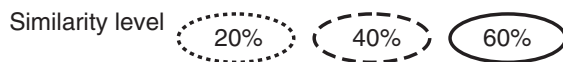

Figure 2 Non-metric multidimensional scaling plots of the arbuscular mycorrhizal fungal (AMF) community; (a) on different plant types sampled from common sites $(n=12)$, (b) on bait Trifolium repens from sites with different land uses $(n=37 ; 3$ outliers sites are not shown), and (c) on field Lolium perenne from pasture sites with different soil types $(n=12)$. Each point on the plot represents a site's AMF community. Plots were derived using Bray-Curtis resemblance matrices generated using terminalrestriction fragment data. Ellipses represent superimposed hierarchical clusters deduced using Bray-Curtis resemblance matrices. do not, as both geographical distance and environmental effect were found to influence AMF distribution (Kivlin et al., 2011).

Environmental variables explained variation in the AMF communities, and were correlated with the variation of the AMF beta diversity, unlike geographical distance. Soil $\mathrm{pH}$ and rainfall were significant drivers for the field L. perenne AMF, and rainfall for the bait T. repens AMF. Previous spore-based studies have shown soil $\mathrm{pH}$ and rainfall to influence AMF sporulation (Wang, 1993; Lovelock et al., 2003), spore density and richness (Johnson et al., 1991; Tchabi et al., 2008), extraradical mycelium growth (van Aarle et al., 2002) and spore community composition (Anderson et al., 1984; Coughlan et al., 2000; Fitzsimons et al., 2008). In addition, AMF communities of $L$. perenne in pastures were influenced by soil type. These results are supported by the spore-based study of Oehl et al. (2010), which found several of their 61 detected AMF species to be associated with a specific soil type.

Several previous studies conducted in various ecosystems have shown that a wide variety of cooccurring plant species can harbour different AMF communities (Helgason et al., 2002; Husband et al., 2002; Vandenkoornhuyse et al., 2002, 2003; Gollotte et al., 2004; Scheublin et al., 2004; Santos-González et al., 2007; Sýkorová et al., 2007a). Only a few studies have found no significant differences between the AMF communities of co-occurring plant species (Opik et al., 2003; Santos et al., 2006). In our study, the distribution of AMF in the roots of co-occurring $T$. repens and $L$. perenne was non-random and these hosts possessed distinctly different AMF communities across the 12 pasture sites sampled. This was supported by the T-RFLP data $(17 \%$ of T-RFs were common to both plant species across all sites), and to a lesser extent the sequencing data $(50 \%$ of sequence groups being common to both plant species from pasture site 1176). AMF community differences between plant

Table 4 Number of terminal-restriction fragments (T-RFs) between the soil types

\begin{tabular}{|c|c|c|c|c|c|c|c|c|c|}
\hline \multirow[t]{2}{*}{ Soil type } & \multicolumn{3}{|c|}{$\begin{array}{l}\text { Bait T. repens from } \\
\text { pasture sites }\end{array}$} & \multicolumn{3}{|c|}{$\begin{array}{l}\text { Bait T. repens from } \\
\text { arable sites }\end{array}$} & \multicolumn{3}{|c|}{$\begin{array}{l}\text { Field L. perenne from } \\
\text { pasture sites }\end{array}$} \\
\hline & $\begin{array}{l}\text { Total no. of } \\
\text { T-RFs }\end{array}$ & $\begin{array}{l}\text { Mean T-RFs } \\
\text { across sites }\end{array}$ & s.d. & $\begin{array}{l}\text { Total no. of } \\
\text { T-RFs }\end{array}$ & $\begin{array}{l}\text { Mean T-RFs } \\
\text { across sites }^{a}\end{array}$ & s.d. & $\begin{array}{l}\text { Total no. of } \\
\text { T-RFs }\end{array}$ & $\begin{array}{l}\text { Mean T-RFs } \\
\text { across sites }^{a}\end{array}$ & s.d. \\
\hline Lithosols & 74 & 28 & 16 & - & - & - & - & - & - \\
\hline $\begin{array}{l}\text { Shallow brown } \\
\text { earths }\end{array}$ & 58 & 29 & 21 & - & - & - & 104 & 58 & 19 \\
\hline $\begin{array}{l}\text { Acid brown } \\
\text { earths }\end{array}$ & 87 & 54 & 20 & 57 & 28 & 13 & 127 & 73 & 20 \\
\hline $\begin{array}{l}\text { Grey brown } \\
\text { podzolics }\end{array}$ & 72 & 36 & 23 & 37 & 14 & 14 & - & - & - \\
\hline Brown podzolics & 95 & 53 & 14 & 30 & 14 & 11 & 109 & 59 & 11 \\
\hline Podzols & 72 & 44 & 9 & - & - & - & - & - & - \\
\hline Gleys & 48 & 30 & 14 & 81 & 44 & 26 & 148 & 73 & 50 \\
\hline
\end{tabular}

${ }^{\mathrm{a}}$ Means based on three sites for each soil type. 
species may not represent 'local host preferences', but is a phenomenon that occurs at larger geographical scales. How AMF plant-host preference is regulated in nature in terms of top-down (plant host) and bottom-up (fungal symbiont) control is not clearly understood. As two different types of plants were sampled, a grass (L. perenne) and a legume ( $T$. repens), which have distinct differences in root morphology and phosphorus requirements (Schweiger, 1994), this may be a contributing factor to the host preference effect observed.

Somewhat surprisingly, there was little influence of land use on AMF T-RF richness and community composition of the bait T. repens. A wide range of land-use types were included in the study (e.g., arable, pastures and peatlands), which differed markedly in the associated vegetation and management practices. Previous studies have shown that plant community structure can influence AMF communities, and thus vegetation differences across sites were expected to have a community effect (Johnson et al., 1992, 2004; Landis et al., 2004; Fitzsimons et al., 2008; Hausmann and Hawkes, 2009). In addition, different agricultural management systems have been shown to affect AMF community composition, with distinct communities found between organic and conventional farming (Oehl et al., 2004; van der Gast et al., 2011) and between agroecosystems varying from seminatural grasslands to intensively cropped arable fields (Oehl et al., 2003, 2010). However, it appears that it is specific management practices, such as tillage (Jansa et al., 2002) and grazing (Eom et al., 2001), rather than broad management categories that drive differences between agroecosystems, and our results suggest that it is specific environmental variables of sites, such as soil $\mathrm{pH}$ and rainfall, that vary within land uses have a stronger effect than land use itself on AMF communities.

Alternatively, the lack of a land-use effect found on the AMF community of the bait T. repens could be a methodological artefact. The bait T. repens plants yielded a different AMF community composition than the field-collected T. repens. The bait plants highlighted different and lower numbers of T-RFs (only $6 \%$ of T-RFs were shared, and field T. repens had $2 \times$ more T-RFs), and different sequence groups. Sequence data from previous studies, based on one or two field sites, have also shown differences in AMF communities between bait and field plants (Opik et al., 2003; Sýkorová et al., 2007b). Likely, the longer exposure time to a larger quantity of soil containing AMF propogules for field plants compared with bait plants contributes to the difference in the AMF communities observed. Also, differences between the community compositions could be attributed to the preferential occurrence of certain species in mature established root systems and later stages of succession, and the influential effects from plant neighbours in a natural system (Sýkorová et al., 2007b; Hausmann and Hawkes, 2009).
The bait-plant method has the advantage of enabling comparisons of in situ AMF communities between multiple sites without confounding factors that affect the AMF colonisation of plant roots, such as various plant (e.g., plant species, genotype and development) and environmental (e.g., light, temperature and soil moisture) variables (Helgason and Fitter, 2009). However, using bait plants to infer AMF biogeographical patterns could be misleading. The AMF communities on the roots of the same plant species ( $T$. repens), but from different approaches (bait vs field) shared few T-RFs and resulted in different relation to environmental variables. Further investigation is warranted to better understand this group of AMF, which colonises bait plants but not field plants. Due to the bias of the bait-plant approach and that AMF-plant host preferences exist at the landscape scale, to better capture AMF diversity a wide range of plant species should be collected from sites and the bait-plant approach used to complement that of field plants. Despite the difference in the AMF communities between the bait and field plants, both AMF compositions were not influenced by geographical distance.

Understanding AMF distributional patterns is important due to the role they play in ecosystem functioning, and because of the current environmental threats to AMF diversity (Turrini and Giovannetti, 2012). Here, we show that the landscape-scale distribution of the AMF communities on plant roots was driven by the local environment, with soil characteristics playing a vital role. Also, roots of $L$. perenne and $T$. repens were shown to support contrasting communities of AMF, and the nature of communities colonising each plant was consistent across pasture habitats and over distance. Our results also demonstrate the strong influence plant host and sampling method have on determining AMF community composition. Advances in sampling approaches and assessment of AMF diversity will further improve our understanding of AMF biogeography. To date, there are a limited number of studies on AMF spatial scaling. Additional studies would provide a more comprehensive view on whether geographical and/or environmental factors shape the distribution of AMF at various spatial scales.

\section{Acknowledgements}

We thank Aidan Keith, Peter Mullin, Dillon Finan, Bas Boots and Fintan Bracken for assistance in field sampling, and members of the SoilC Project (University College Cork, Ireland) for provision of soils data, and also Dr Ruth Mitchell (The James Hutton Institute) for assistance with statistical analyses. This study was funded by the Environmental ERDTI Programme 2000-2006, financed by the Irish Government under the National Development Plan and administered on behalf of the Department of Environment and Local Government by the Environmental Protection 
Agency ('CréBeo: Baseline data, response to pressures, functions and conservation of keystone microorganisms and macroorganisms in Irish soils', 2005-S-LS-8).

\section{References}

Anderson RC, Liberta AE, Dickman LA. (1984). Interaction of vascular plants and vesicular-arbuscular mycorrhizal fungi across a soil moisture-nutrient gradient. Oecologia 64: 111-117.

Baas-Becking LGM. (1934). Geobiologie of Inleiding Tot de Milieukunde. WP Van Stockkum and Zoon: The Hague, The Netherlands.

Borcard D, Legendre P, Avois-Jacquet C, Tuomisto H. (2004). Dissecting the spatial structure of ecological data at multiple scales. Ecology 85: 1826-1832.

Borcard D, Legendre P. (2002). All-scale spatial analysis of ecological data by means of principal coordinates of neighbour matrices. Ecol Model 153: 51-68.

Bray JR, Curtis JT. (1957). An ordination of the upland forest communities of southern Wisconsin. Ecol Monogr 27: 325-349.

Brundrett MC. (2009). Mycorrhizal associations and other means of nutrition of vesicular plants: understanding the global diversity of host plants by resolving conflicting information and developing reliable means of diagnosis. Plant Soil 320: 37-77.

Chaudhary VB, Lau MK, Johnson NC. (2008). Macroecology of microbes-biogeography of the glomeromycota. In: Varma A (ed) Mycorrhiza, 3rd edn. Springer: Berlin, Germany, pp 529-563.

Clarke KR. (1993). Non-parametric multivariate analysis of change in community structure. Aust J Ecol 18: 117-143.

Clarke KR. (1999). Non-metric multivariate analysis in community-level ecotoxicology. Environ Toxicol Chem 18: 118-127.

Coughlan AP, Dalpé Y, Lapointe L, Piché Y. (2000). Soil $\mathrm{pH}$-induced changes in root colonization, diversity of symbiotic arbuscular mycorrhizal fungi from healthy and declining maple forest. Can J Forest Res 30: 1543-1554.

Douhan GW, Peterson C, Bledsoe CS, Rizzo DM. (2005). Contrasting root associated fungi of three common oak-woodland plant species based on molecular identification: host specificity or non-specific amplification. Mycorrhiza 15: 365-372.

Dray S, Legendre P, Peres-Neto PR. (2006). Spatial modelling: a comprehensive framework for principal coordinate analysis of neighbour matrices (PCNM). Ecol Model 196: 483-493.

Dumbrell AJ, Nelson M, Helgason T, Dytham C, Fitter AH. (2010). Relative roles of niche and neutral processes in structuring a soil microbial community. ISME J 4: 337-345.

Eom AH, Wilson GWT, Hartnett DC. (2001). Effects of ungulate grazers on arbuscular mycorrhizal symbiosis and fungal community structure in tallgrass prairie. Mycologia 93: 233-242.

Fay D, Kramers G, Zhang C, McGrath D, Grennan E. (2007b). Soil Geochemical Atlas of Ireland. Teagasc and the Environmental Protection Agency: Ireland.

Fay D, McGrath D, Zhang C, Carrigg C, O'Flaherty V, Carton OT et al. (2007a). Towards a National Soils Database, 2001-CD/S2-M2 Final Report, ERTDI Programme, 2000-2006. Environmental Protection Agency: Ireland.
Fierer N, Jackson RB. (2006). The diversity and biogeography of soil bacterial communities. PNAS 103: 626-631.

Fitter AH. (2005). Darkness visible: reflections on underground ecology. J Ecol 93: 231-243.

Fitzsimons MS, Miller RM, Jastrow JD. (2008). Scaledependent niche axes of arbuscular mycorrhizal fungi. Oecologia 158: 117-127.

Gollotte A, van Tuinen D, Atkinson D. (2004). Diversity of arbuscular mycorrhizal fungi colonising roots of the grass species Agrostis capillaries and Lolium perenne in a field experiment. Mycorrhiza 14: 111-117.

Green JL, Holmes AJ, Westoby M, Briscoe D, Dangerfield M, Gillings M et al. (2004). Spatial scaling of microbial eukaryote diversity. Nature 432: 747-750.

Hammer Ø, Harper DAT, Ryan PD. (2001). PAST: Paleontological statistics software package for education and data analysis. Palaeontol Electronica 4: 9.

Hartnett DC, Wilson WT. (1999). Mycorrhizae influence plant community structure and diversity in tallgrass prairie. Ecology 80: 1187-1195.

Hausmann NT, Hawkes CV. (2009). Plant neighborhood control of arbuscular mycorrhizal community composition. New Phytol 183: 1188-1200.

Helgason T, Daniell TJ, Husband R, Fitter AH, Young JPW. (1998). Ploughing up the wood-wide web? Nature 394: 431.

Helgason T, Fitter AH. (2009). Natural selection and the evolutionary ecology of the arbuscular mycorrhizal fungi (Phylum Glomeromycota). J Exp Bot 60: 2465-2480.

Helgason T, Merryweather JW, Denison J, Wilson P, Young JPW, Fitter AH. (2002). Selectivity and functional diversity in arbuscular mycorrhizas of co-occurring fungi and plants from a temperate deciduous woodland. J Ecol 90: 371-384.

Husband R, Herre EA, Turner SL, Galler R, Young JPW. (2002). Molecular diversity of arbuscular mycorrhizas of co-occurring fungi and plants from a temperate deciduous woodland. J Ecol 90: 371-384.

Jansa J, Mozafar A, Anken T, Ruh R, Sanders IR, Frossard E. (2002). Diversity and structure of AMF communities as affected by tillage in a temperate soil. Mycorrhiza 12: 255-234.

Johnson D, Vandenkoornhuyse PJ, Leake JR, Gilbert L, Booth RE, Grime JP et al. (2004). Plant communities affect arbuscular mycorrhizal fungal diversity and community composition in grassland microcosms. New Phytol 161: 503-515.

Johnson NC, Tilman D, Wedin D. (1992). Plant and soil controls on mycorrhizal fungal communities. Ecology 73: 2034-2042.

Johnson NC, Zak DR, Tilman D, Pfleger FL. (1991). Dynamics of vesicular arbuscular mycorrhizae during old field succession. Oecologia 86: 349-358.

Kelly G, Carton O. (2009). SoilC-measurement and modelling of soil carbon stocks and stock changes in Irish soils Datasets available at: Secure Archive for Environmental Research Data managed by Environmental Protection AgencyIrelandhttp://erc.epa.ie/ safer/iso19115/displayISO19115.jsp?isoID=107.

Kivlin SN, Hawkes CV, Treseder KK. (2011). Global diversity and distribution of arbuscular mycorrhizal fungi. Soil Biol Biochem 43: 2294-2303.

Klironomos JN, McCune J, Hart M, Neville J. (2000). The influence of arbuscular mycorrhizae on the relationship between plant diversity and productivity. Ecol Lett 3: 137-141. 
Kruskal JB. (1964). Multidimensional scaling by optimizing goodness of fit to a nonmetric hypothesis. Psychometrika 29: 1-27.

Kruskal JB, Wish M. (1978). Multidimensional Scaling. Sage University Paper series on Quantitative Application in the Social Sciences, number 07-011. Sage Publications: Newbury Park, CA, USA.

Landis FC, Gargas A, Givnish RJ. (2004). Relationship among arbuscular mycorrhizal fungi, vesicular plants and environmental conditions in oak savannas. New Phytol 164: 493-504.

Lauber CL, Hamady M, Knight R, Fierer N. (2009). Pyrosequencing-based assessment of soil $\mathrm{pH}$ as a predictor of soil bacterial community structure at the continental scale. Appl Environ Microbiol 75: 5111-5120.

Lekberg Y, Koide RT, Rohr JR, Aldrich-Wolf L, Morton JB. (2007). Role of niche restrictions and dispersal in the composition of arbuscular mycorrhizal fungal communities. I Ecol 95: 95-105.

Lovelock CE, Anderson K, Morton JB. (2003). Arbuscular mycorrhizal communities in tropical forests are affected by host tree species and environment. Oecologia 135: 268-279.

Mantel N. (1967). The detection of disease clustering and a generalized regression approach. Cancer Res 27: 209-220.

Martiny JBH, Bohannan BJM, Brown JH, Colwell RK, Fuhrman JA, Green JL et al. (2006). Microbial biogeography: putting microorganisms on the map. Nature 4: 102-112.

Martiny JBH, Eisen JA, Penn K, Allison SD, Horner-Devine MC. (2011). Drivers of bacterial $\beta$-diversity depends on spatial scale. PNAS 108: 7850-7854.

McCune B, Mefford MJ. (1999). PC-ORD. Multivariate Analysis of Ecological Data Version 5.0, MjM Software, Gleneden Beach, OR, USA.

Mummey DL, Rillig MC, Holben WE. (2005). Neighboring plant influences on arbuscular mycorrhizal fungal community composition as assessed by T-RFLP analysis. Plant Soil 271: 83-90.

Nemergut DR, Costello EK, Hamady M, Lozupone C, Jiang L, Schmidt SK et al. (2011). Global patterns in biogeography of bacterial taxa. Environ Microbiol 13: 135-144.

O'Connor PJ, Smith SE, Smith EA. (2002). Arbuscular mycorrhizas influence plant diversity and community structure in a semiarid herbland. New Phytol 154: 209-218.

Oakley BB, Carbonero F, van der Gast CJ, Hawkins RJ, Purdy KJ. (2010). Evolutionary divergence and biogeography of sympatric nich-differentiated bacterial populations. ISME J 4: 488-497.

Oehl F, Laczko E, Bogenrieder A, Stahr K, Bösch R, van der Heijden $\mathrm{M}$ et al. (2010). Soil type and land use intensity determines the compostion of arbuscular mycorrhizal fungal communities. Soil Biol Biochem 42: 724-738.

Oehl F, Sieverding E, Ineichen K, Mäder P, Boller T, Wiemken A. (2003). Impact of land use intensity on the species diversity of arbuscular mycorrhizal fungi in agroecosystems of central Europe. Appl Environ Microbiol 69: 2816-2824.

Oehl F, Sieverding E, Mäder P, Dubois D, Ineichen K, Boller T et al. (2004). Impact of long-term conventional and organic farming on the diversity of arbuscular mycorrhizal fungi. Oecologia 138: 574-583.

Opik M, Metsis M, Daniell TJ, Zobel M, Moora M. (2009). Large-scale parallel 454 sequencing reveals ecological group specificity of arbuscular mycorrhizal fungi in a boreonemoral forest. New Phytol 184: 424-437.

Opik M, Moora M, Liira J, Kõljalg U, Zobel M, Sen R. (2003). Divergent arbuscular mycorrhizal fungi communities colonise roots of Pulsatilla spp. in boreal Scots pine forest and grassland soils. New Phytol 160: 581-593.

Opik M, Moora M, Liira J, Zobel M. (2006). Composition of root-colonizing arbuscular fungal communities in different ecosystems around the globe. J Ecol 94: 778-790.

Opik M, Vanatoa A, Vanatoa E, Moora M, Davison J, Kalwij JM et al. (2010). The online database MaarjAM reveals global and ecosystem distribution patterns in arbuscular mycorrhizal fungi (Glomeromycota). New Phytol 188: 223-241.

Peres-Neto PR, Legendre P, Dray S, Borcard D. (2006). Variation partitioning of species data matrices: estimation and comparison of fractions. Ecology 87: 2614-2625.

Prosser JI, Bohannan BJM, Curtis TP, Ellis RJ, Firestone MK, Freckleton RP et al. (2007). The role of ecological theory in microbial ecology. Nat Rev Microbiol 5: 384-392.

Ramette A, Tiedje JM. (2007a). Biogeography: an emerging cornerstone for understanding prokaryotic diversity, ecology, and evolution. Microb Ecol 53: 197-207.

Ramette A, Tiedje JM. (2007b). Multiscale responses of microbial life to spatial distance and environmental heterogeneity in a patchy ecosystem. PNAS 104: $2761-2766$

Redecker D. (2000). Ancestral lineages of arbuscular mycorrhizal fungi (Glomales). Mol Phylogenet Evol 14: 276-284.

Roesch LFW, Fulthorpe RR, Riva A, Casella G, Hadwin AKM, Kent AD et al. (2007). Pyrosequencing enumerates and contrasts soil microbial diversity. ISME J 1: 283-290.

Rosendahl S. (2008). Communities, populations and individuals of arbuscular mycorrhizal fungi. New Phytol 178: 253-266.

Rossi JP. (1996). Statistical tool for soil biology. XI. Autocorrelogram and Mantel test. Eur J Soil Biol 32: 195-203.

Sanders IR. (2004). Plant and arbuscular mycorrhizal fungal diversity-are we looking at the relevant levels of diversity and are we using the right techniques? New Phytol 164: 415-418.

Santos JC, Finlay RD, Tehler A. (2006). Molecular analysis of arbuscular mycorrhizal fungi colonising a seminatural grassland along a fertilisation gradient. New Phytol 172: 159-168.

Santos-González JC, Finlay RD, Tehler A. (2007). Seasonal dynamics of arbuscular mycorrhizal fungal communities in roots in a seminatural grassland. Appl Environ Microbiol 73: 5613-5623.

Schauer R, Bienhold C, Ramette A, Harder J. (2010). Bacterial diversity and biogeography in deep-sea surface sediments of the South Atlantic Ocean. ISME J 4: 159-170.

Scheublin TR, Ridgway KP, Young JPW, van der Heijden MGA. (2004). Nonlegumes, legumes, and root nodules harbor different arbuscular mycorrhizal fungal communities. Appl Environ Microbiol 70: 6240-6246.

Scheublin TR, van Logtestijn RSP, van der Heijden MGA. (2007). Presence and identity of arbuscular mycorrhizal fungi influence competitive interactions between plant species. J Ecol 95: 631-638. 
Schweiger P. (1994). Factors Affecting VA Mycorrhizal Uptake of Phosphorus $\mathrm{PhD}$ thesis, The University of Western Australia.

Simon L, Lalonde M, Bruns TD. (1992). Specific amplification of $18 \mathrm{~S}$ fungal ribosomal genes from vesiculararbuscular endomycorrhizal fungi colonising roots. Appl Environ Microbiol 58: 291-295.

Smouse PE, Long JC, Sokal RR. (1986). Multiple regression and correlation extensions of the Mantel test of matrix correspondence. Syst Zool 35: 627-632.

Sýkorová Z, Ineichen K, Wiemken A, Redecker D. (2007b). The cultivation bias: different communities of arbuscular mycorrhizal fungi detected in roots from the field, from bait plants transplanted to the field, and from a greenhouse trap experiment. Mycorrhiza 18: 1-14.

Sýkorová Z, Wiemken A, Redecker D. (2007a). Co-occurring Gentiana verna and Gentiana acaulis and their neighboring plants in two Swiss upper montane meadows harbor distinct arbuscular mycorrhizal fungal communities. Appl Environ Microbiol 73: 5426-5434.

Tchabi A, Coyne D, Hountondij F, Lawouin L, Wiemken A, Oehl F. (2008). Arbuscular mycorrhizal fungi communities in sub-Saharan savannas of Benin, West Africa, as affected by agricultural land use intensity and ecological zone. Mycorrhiza 18: 181-195.

ter Braak CJF, Smilauer P. (2002). CANOCO reference manual and user's guide to Canoco for Windows: Software for Canonical Community Ordination (version 4.5) Microcomputer Power, Ithaca, NY, USA.

Tuomisto H, Ruokolainen K. (2006). Analyzing or explaining beta diversity? Understanding the targets of different methods of analysis. Ecology 87: 2697-2708.

Turrini A, Giovannetti M. (2012). Arbuscular mycorrhizal fungi in national parks, nature reserves and protected areas worldwide: a strategic perspective for their in situ conservation. Mycorrhiza 22: 81-97.

van Aarle IM, Olsson PA, Söderström B. (2002). Arbuscular mycorrhizal fungi respond to the substrate $\mathrm{pH}$ of their extraradical mycelium by altered growth and root colonisation. New Phytol 155: 173-182. van der Gast CJ, Gosling P, Tiwari B, Bending GD. (2011). Spatial scaling of arbuscular mycorrhizal fungal diversity is affected by farming practice. Environ Microbiol 13: 241-249.

van der Heijden MGA, Bardgett RD, van Straalen NM. (2008). The unseen majority: soil microbes as drivers of plant diversity and productivity in terrestrial ecosystems. Ecol Lett 11: 296-310.

van der Heijden MGA, Boller T, Wiemken A, Sanders IR. (1998a). Different arbuscular mycorrhizal fungal species are potential determinates of plant community structure. Ecology 79: 2082-2091.

van der Heijden MGA, Klironomos JN, Ursic M, Moutoglis $\mathrm{P}$, Streitwolf-Engel R, Boller T et al. (1998b). Mycorrhizal fungi diversity determines plant biodiversity, ecosystems variability and production. Nature 396: 69-72.

van der Heijden MGA, Wiemken A, Sanders IR. (2003). Different arbuscular mycorrhizal fungi alter coexistence and resource distribution between co-occurring plants. New Phytol 157: 569-578.

Vandenkoornhuyse P, Husband R, Daniell TJ, Watson IJ, Duck JM, Fitter AH et al. (2002). Arbuscular mycorrhizal community composition associated with two plant species in a grassland ecosystem. Mol Ecol 11: 1555-1564.

Vandenkoornhuyse P, Ridgway KP, Watson IJ, Fitter AH, Young JPW. (2003). Co-existing grass species have distinct arbuscular mycorrhizal communities. Mol Ecol 12: 3085-3095.

Wang B, Qiu YL. (2006). Phylogentic distribution and evolution of mycorrhizas in land plants. Mycorrhiza 16: 299-363.

Wang GM. (1993). Effect of $\mathrm{pH}$ on arbuscular mycorrhiza, I. Field observation on the long term liming experiment at Rothamsted and Woburn. New Phytol 124: 465-472.

Wang J, Wu Y, Jlang H, Li C, Dong H, Wu Q. (2008). High beta diversity of bacteria in the shallow terrestrial subsurface. Environ Microbiol 10: 2537-2549.

Supplementary Information accompanies the paper on The ISME Journal website (http://www.nature.com/ismej) 